\title{
PENGATURAN DOKTRIN DILUSI MEREK SEBAGAI UPAYA PERLINDUNGAN HUKUM MEREK TERKENAL DI INDONESIA*
}

\author{
Inge Dwisvimiar ** \\ Bagian Hukum Perdata Fakultas Hukum Universitas Sultan Ageng Tirtayasa, Banten \\ Jalan Raya Jakarta Km 04 Pakupatan, Serang, Banten 42124
}

\begin{abstract}
This research aims at 1) digging and analyzing the regulation of Trademark Dilution as a means of giving protection for those who hold well-known trademark which is stated in Indonesia Law; and 2) analyzing and finding whether it is necessary or not to do the regulation of trademark dilution in Indonesia. The result of research shows that: 1) regulation of trademark dilution is a way to protect the owner of wellknown trademark which is stated in Law of Indonesia chapter 6 article (2) of the Law of trademark 2001. It is based on chapter 16 article (3) TRIPS; 2. for the recommendation of Trademark Dilution, it is put in the revision of trademark in future Law by strengthening Article 6 (2) 2001 in Law of trademark 2001. Keywords: trademark dilution doctrine, law protection, well-known trademark.
\end{abstract}

\section{Intisari}

Penelitian ini bertujuan: 1. Untuk menggali dan menganalisis pengaturan Dilusi Merek sebagai cara pemberian perlindungan hukum bagi pemegang Merek Terkenal dalam peraturan perundang-undangan Indonesia dan negara lain serta Konvensi Internasional; 2. Untuk menganalisis dan menemukan perlu atau tidaknya dilakukan pengaturan dilusi merek di Indonesia. Hasil penelitian menunjukkan: 1. Pengaturan Dilusi Merek sebagai cara pemberian perlindungan hukum bagi pemegang Merek Terkenal dalam peraturan perundang-undangan Indonesia dengan menggunakan penyesuaian Pasal 6 ayat (2) UUM 2001 berdasarkan Pasal 16 ayat (3) TRIPs. 2. Dalam prospek perbaikan pengaturan dilusi merek di Indonesia perlu dipertimbangkan dengan memperkuat Pasal 6 ayat (2) UUM 2001.

Kata Kunci: doktrin dilusi merek, perlindungan hukum, merek terkenal.

\section{Pokok Muatan}

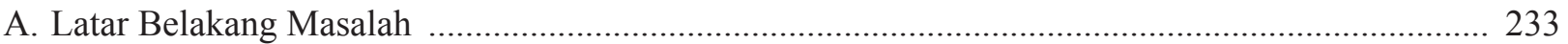

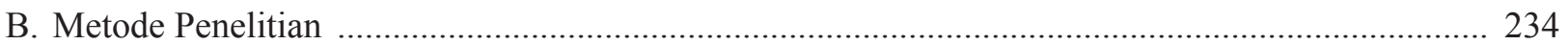

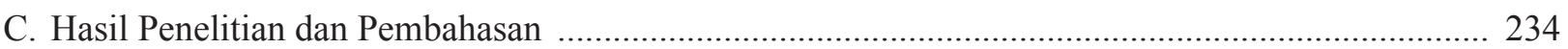

1. Pemilik Merek Terkenal di Indonesia Dapat Menggugat Pihak Lain yang Telah Mendilusi

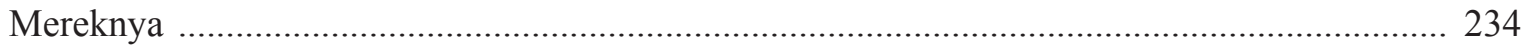

2. Pengaturan Doktrin Dilusi Merek ........................................................................................ 240

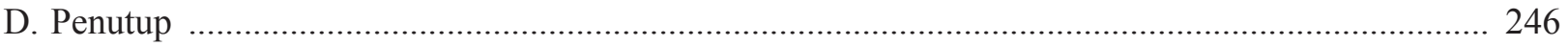

Penelitian Disertasi Doktor Didanai DP2M Dikti Tahun 2015.

Alamat korespondensi: inged945@gmail.com. 


\section{A. Latar Belakang Masalah}

Salah satu bidang Kekayaan Intelektual adalah merek yang merupakan tanda untuk mengidentifikasi asal barang dan atau jasa (an indication of origin). Di Indonesia, pengaturan mengenai merek terdapat dalam Undang-Undang Nomor 15 Tahun 2001 tentang Merek selanjutnya disingkat UUM 2001. UUM 2001 memberikan perlindungan kepada pemegang/pemilik merek berupa hak eksklusif yang diberikan oleh negara untuk menggunakan, memberi ijin dan melarang penggunaan tidak syah yang dilakukan oleh produsen atau pihak-pihak yang mempunyai itikad tidak baik berupa peniruan, pembajakan bahkan mungkin pemalsuan merek. ${ }^{1}$

Perkara-perkara merek yang tercatat di Pengadilan Niaga Jakarta Pusat dan Mahkamah Agung Republik Indonesia adalah perkara yang menyangkut kasus merek terkenal. Adanya kasus-kasus tersebut dapat merugikan pemilik merek terkenal. Selain itu, kasus-kasus tersebut juga merugikan masyarakat umum, khususnya para konsumen. Dalam hal ini, pelanggaran merek merupakan perbuatan curang yang menciptakan kekacauan mengenai asal-usul barang atau usaha industri dan dagang, mendiskreditkan usaha pengusaha atau barang industrial dan komersial pemilik merek yang sesungguhnya, serta mengelabui khalayak ramai berkenaan dengan kualitas suatu barang. ${ }^{2}$

Penggunaan merek terkenal secara sengaja, tanpa hak, dan melawan hukum oleh pihak tertentu memperlihatkan adanya pelanggaran merek dengan didasarkan pada itikad tidak baik yang mempunyai persamaan pada pokoknya atau keseluruhannya dengan merek terkenal pihak lain untuk barang dan atau/jasa yang sejenis. ${ }^{3}$ Pelanggaran dimaksud, telah menyebabkan terjadinya kemungkinan kebingungan (likelihood of confusion) bagi masyarakat awam.

Di Amerika Serikat dan sejumlah negara lain, untuk melindungi mereknya, pemilik merek terkenal dapat menggunakan alasan dilusi merek (trademark dilution) di samping alasan pelanggaran merek (trademark infringement) seperti telah diuraikan di atas. Dalam sistem common law, dilusi merek ini dimasukkan ke dalam perlindungan hukum merek dan dinamakan doktrin dilusi merek. Doktrin dilusi merek adalah prinsip dalam hukum merek yang mengizinkan pemilik merek terkenal untuk melarang pihak lain menggunakan merek mereka dengan cara-cara yang dapat mengancam keunikan merek tersebut. ${ }^{4}$ Sebuah merek didilusi ketika suatu pihak menggunakan merek yang sama atau identik dengan merek milik pihak lain dalam barang yang tidak berkompetisi (barang yang tidak sejenis) yang dapat mengurangi kekuatan merek tersebut sehingga dapat mengakibatkan kebingungan konsumen mengenai sumber asal mereknya. ${ }^{5}$

UUM 2001 tidak berisi ketentuan tentang dilusi merek. Undang-undang tersebut tidak menyebutkan istilah dilusi merek dalam semua Pasalnya. UUM 2001 hanya menegaskan dalam Pasal 6 ayat (1) huruf b bahwa "Permohonan harus ditolak oleh Direktorat Jenderal apabila merek tersebut mempunyai persamaan pada pokoknya atau keseluruhannya dengan merek yang sudah terkenal milik pihak lain untuk barang dan/atau jasa sejenis." Kemudian dalam Pasal 6 ayat (2) UUM disebutkan bahwa "ketentuan sebagaimana dimaksud pada ayat (1) huruf b dapat pula diberlakukan terhadap barang dan/atau jasa yang tidak sejenis sepanjang memenuhi persyaratan tertentu yang akan ditetapkan lebih lanjut dengan Peraturan Pemerintah.”

Berdasarkan ketentuan Pasal 6 ayat (1) huruf b dan Pasal 6 ayat (2), adanya pihak yang

Hak atas Merek adalah hak eksklusif yang diberikan oleh negara kepada pemilik Merek yang terdaftar dalam Daftar Umum Merek untuk jangka waktu tertentu dengan menggunakan sendiri Merek tersebut atau memberikan izin kepada pihak lain untuk menggunakannya. Lebih lanjut lihat pada Pasal 3 Undang-Undang Nomor 15 Tahun 2001 tentang Merek (Lembaran Negara Republik Indonesia Tahun 2001 Nomor 110, Tambahan Lembaran Negara Republik Indonesia Nomor 4131).

Cita Citrawinda, "Sekilas Tentang Tindak Pidana dalam Bidang Merek", http://iwan09file.wordpress.com/mengenai-permasalahan-merek/, diakses Tanggal 21 Desember 2013.

Lihat Pasal 6 ayat (1) huruf b dan Pasal 6 ayat (2) Undang-Undang Nomor 15 Tahun 2001 tentang Merek (Lembaran Negara Republik Indonesia Tahun 2001 Nomor 110, Tambahan Lembaran Negara Republik Indonesia Nomor 4131).

Brajendu Bhaskar, "Trademark Dilution Doctrine: The Scenario Post TDRA 2005”, NJUS L. Rev, Oct-December, 2008, hlm. 637.

Ibid. 
mengajukan permohonan sebagaimana dimaksud dalam pasal itu dapat dikategorikan ke dalam pelanggaran merek (trademark infringement). Pelanggaran terjadi ketika seseorang selain dari pemegang merek menggunakan merek secara melawan hukum yang menyebabkan kebingungan konsumen. Dilusi berbeda dari pelanggaran merek biasa karena dilusi tidak membutuhkan bukti adanya kemungkinan kebingungan pada konsumen. Dengan demikian, yang dibutuhkan adalah bukti bahwa penggunaan dari merek terkenal oleh pihak ketiga dapat menyebabkan berkurangnya kekuatan dari daya pembeda merek tersebut.

Sehubungan dengan hal-hal tersebut di atas, pengaturan dilusi merek dalam UUM merupakan unsur yang penting dikarenakan memberikan hak yang lebih luas kepada pemilik merek terkenal untuk mencegah atas penggunaan yang tidak membingungkan dalam rangka untuk melindungi keunikan dari merek mereka melawan blurring dan tarnishment, yang berbeda dari hanya pelanggaran merek biasa (trademark infringement). Selain itu, dengan menggunakan doktrin dilusi merek maka perlindungan terhadap merek terkenal akan lebih efektif. ${ }^{6}$

Berdasarkan uraian latar belakang masalah di atas, maka dapat dirumuskan masalah sebagai berikut: Pertama, dapatkah pemilik merek terkenal di Indonesia menggugat pihak lain yang telah mendilusi mereknya ? Kedua, apakah doktrin dilusi merek perlu diatur ataukah tidak?

\section{B. Metode Penelitian}

Penelitian ini merupakan penelitian hukum normatif. Dalam permasalahan pertama ini akan dikemukakan perundang-undangan yang dapat dijadikan dasar landasan atas alasan gugatan dilusi merek oleh pemilik merek di Indonesaia. Dalam permasalahan kedua akan dilakukan penelitian mengenai perlu atau tidaknya pengaturan mengenai doktrin dilusi merek terkenal di Indonesia. Adapun pendekatan masalah dalam penelitian adalah statute approach (pendekatan perundang-undangan), conseptual approach (pendekatan konseptual) dan comparative approach (pendekatan perbandingan). Sumber data yang digunakan dalam penelitian ini adalah data sekunder. Tujuan pengambilan data sekunder ini sebagai eksplorasi sehingga dapat diperoleh gambaran yang lebih jelas tentang masalahnya dan mungkin petunjuk-petunjuk tentang cara memecahkannya.

Data-data hukum yang diperoleh dalam penelitian akan diinventarisir, diklasifikasi, diuraikan, dihubungkan dan dianalisis. Analisis data merupakan bagian yang amat penting dalam metode ilmiah, karena dengan analisislah, data tersebut dapat diberi arti dan makna yang berguna dalam memecahkan masalah penelitian. ${ }^{7}$ Guna menjawab permasalahan yang telah diuraikan kemudian diolah secara deduktif yaitu menarik kesimpulan dari suatu permasalahan yang bersifat umum terhadap permasalahan konkret yang dihadapi selanjutnya dalam mengumpulkan, mengolah dan menganalisis bahan ditempuh cara analisis kualitatif.

\section{Hasil Penelitian dan Pembahasan}

1. Pemilik Merek Terkenal di Indonesia Dapat Menggugat Pihak Lain yang Telah Mendilusi Mereknya

Pengaturan mengenai perlindungan merek terkenal di Indonesia terdapat dalam Pasal 6 ayat 1 (b) UUM 2001 berbunyi: "Permohonan harus ditolak oleh Direktorat Jenderal apabila merek tersebut mempunyai persamaan pada pokoknya atau keseluruhannya dengan merek yang sudah terkenal milik pihak lain untuk barang dan atau jasa sejenis." Selanjutnya dalam Pasal 6 ayat (2):"Ketentuan sebagaimana dimaksud pada ayat (1) huruf b dapat pula diberlakukan terhadap barang dan/atau jasa yang tidak sejenis sepanjang memenuhi persyaratan tertentu yang akan ditetapkan lebih lanjut dengan Peraturan Pemerintah". Pasal 6 ayat (2) UUM

\footnotetext{
Stacey L. Dogan dan Mark A. Lemley, "The Trademark use Requirement in Dilution Cases”, Santa Clara Computer \& High Technology Law Journal, Vol.4, No.3, 2008, hlm. 541

Moh. Nazir,2003, Metode Penelitian, Ghalia Indonesia, Jakarta, hlm. 346.
} 
2001 hanya ditujukan kepada perlindungan terhadap pelanggaran merek terkenal ${ }^{8}$ terhadap barang dan/atau jasa yang tidak sejenis dan bukan perlindungan terhadap dilusi merek terkenal. Mengenai pelanggaran merek, dalam The Lanham Act disebutkan bahwa:

Prohibits anyone, without prior consent from the trademark registrant, from using in commerce any "reproduction, counterfeit, copy or colorable imitation of a registered mark in connection with the sale, distribution, or advertising of any goods or services on or in connection with which such use is likely to cause confusion $[. .$.$] mistake, or to deceive. { }^{9}$

Dapat dikemukakan bahwa jika seseorang tanpa persetujuan terlebih dahulu dari pemilik merek dagang terdaftar melakukan reproduksi, memalsukan, menyalin atau membuat hasill imitasi dari merek terdaftar yang mempunyai hubungan dengan penjualan, distribusi, atau iklan barang atau jasa maka pemilik merek terdaftar dapat menuntut pihak lain ketika terjadi pelanggaran merek dagang atas merek miliknya. Standar yang dijadikan acuan adalah "kemungkinan kebingungan". Dengan kata lain, penggunaan merek dalam hubungannya dengan penjualan barang dianggap sebagai pelanggaran jika penggunaan merek tertentu cenderung menyebabkan kemungkinan kebingungan konsumen terhadap sumber barang-barang atau sebagai sponsor atau persetujuan barang-barang tersebut, sebelum, selama, dan setelah putusan pembelian. ${ }^{10}$

Sebaliknya, perlindungan dilusi merek bergantung pada premis yang sama sekali berbeda daripada perlindungan melawan pelanggaran merek.
Perlindungan atas dilusi merek terkenal berdasarkan perlindungan kualitas daya pembeda merek terkenal dan perlindungan reputasi dari pihak-pihak yang dapat menodai merek terkenal, tanpa memperhatikan kebingungan konsumen atas sumber dari produk maupun persaingan diantara keduanya. Dilusi secara umum terjadi melalui pengaburan (blurring) dari merek terkenal atau penodaan (tarnishment) terhadap merek terkenal, tetapi tidak hanya terbatas pada hal-hal tersebut saja. ${ }^{11}$

Dogan mengatakan, "Dilution, as originally conceived, referred to the harm that occurs when a famous, distinctive mark loses its singular meaning" (dilusi menunjuk pada kerugian yang terjadi pada merek yang terkenal. Dalam hal ini, merek yang berbeda kehilangan arti tunggalnya). ${ }^{12}$ Doktrin dilusi dikembangkan secara prinsip di Amerika Serikat. Teori dilusi aslinya berasal dari Jerman, tepatnya tahun 1924, kemudian, tahun 1927 teori dilusi ini dibawa ke Amerika melalui publikasi artikel berjudul "The Rational Basis of Trademark Protection", yang ditulis oleh Frank I. Schechter. ${ }^{13}$ Schechter merujuk artikelnya pada kasus yang timbul lebih awal di Jerman dalam hal pemilik merek ODOL, merek terkenal untuk penyegar mulut, yang telah sukses membatalkan pendaftaran merek yang serupa untuk produk baja. Pengadilan menyatakan,

Such use of the mark ODOL on noncompeting goods was against good morals ("gegen die guten Sitten") and violated the principles of fair trade. The protection was based on the lessening of the mark's selling power and on the impairment of the owner's

UUM pada Pasal 76, Pasal 77, Pasal 78 dan Pasal 79 juga mengatur pelanggaran merek dalam Bab XI Penyelesaian Sengketa, bagian pertama mengenai gugatan atas pelanggaran merek.

Patrick Emerson, “I'm Litigatin' It: Infringement Dilution, and Parody Under the Lanham Act”, Northwestern Journal of Technology and Intellectual Property, Vol.9, No.7, 2011, hlm 479.

10 Harvard Universiry, "Overview of Trademark Law", http://cyber.law.harvard.edu/metaschool/fisher/domain/tm.htm, diakses 1 Desember 2015.

11 Cornel University Law School, “Dilution: Trademark”, https://www.law.cornell.edu/wex/dilution_trademark, diakses 1 Desember 2015.

12 Stacey L. Dogan, "What is dilution, anyway?", http://students.law.umich.edu/mlr/firstimpressions/vol105/dogan.pdf, diakses 1 Desember 2015.

13 William T. Vuk, "Protecting Baywatch And Wagamama: Why The European Union Should Revise The 1989 Trademark Directive To Mandate Dilution Protection For Trademarks", Fordham International Law Journal, Vol.21, No.3, 1997, hlm. 86. 
ability to compete. Thus, dilution protection for famous marks was initially based on the general unfair competition law. ${ }^{14}$

Dalam kasus ODOL, pemilik obat kumur terkenal menggugat untuk menghentikan produsen produk baja dari menggunakan merek ODOL sebagai merek dagangnya. Terlepas dari kenyataan bahwa obat kumur dan produk baja adalah barang yang tidak sejenis atau barang yang tidak berkompetisi, pengadilan Jerman menyimpulkan bahwa pemilik merek ODOL memiliki kepentingan substansial dalam memastikan bahwa merek dagang mereka tidak didilusi. Dari adanya kasus yang terjadi, pengadilan menegaskan bahwa ODOL akan kehilangan kekuatan daya jual jika semua orang memiliki kesempatan untuk menggunakan merek tersebut. Hanya dalam kurun waktu tiga tahun setelah keputusan dalam kasus ini, dilusi mencapai daratan Amerika. ${ }^{15}$

Pelanggaran merek yang dimaksudkan pada Pasal 6 ayat (2) sebagaimana diuraikan sebelumnya adalah sama mengatur barang dan/atau jasa tidak sejenis seperti halnya pada pengaturan dilusi merek, akan tetapi bunyi dari pasal itu sendiri yang menyatakan : "Ketentuan sebagaimana dimaksud pada ayat (1) huruf b dapat pula diberlakukan [...]", sehingga dapat ditafsirkan baik Pasal 6 ayat (1) maupun Pasal 6 ayat (2) secara umum maknanya masih merujuk pada pelanggaran merek (trademark infringement) berdasarkan analisis faktor kemungkinan kebingungan (likelihood of confusion) terhadap pikiran masyarakat yang membeli barang dan atau jasa, sebelum, selama dan setelah putusan pembelian. Adapun mengenai adanya pembedaaan pasal hanya pada klasifikasi kelas barang dan/jasa sejenis dan tidak sejenis saja.

Dalam UUM 2001 tidak diatur adanya hak menggugat bagi pemilik merek terkenal terhadap pihak lain yang telah mendilusi mereknya. Ketentuan Pasal 6 ayat (2) UUM 2001 yang telah diuraikan memperlihatkan bahwa pasal ini mempunyai relevansi dengan Pasal sebelumnya sehingga orang dapat menafsirkan bahwa Pasal 6 ayat (2) merupakan kelanjutan dari Pasal 6 ayat (1) yang mengatur mengenai pelanggaran merek atas klasifikasi jenis barang sejenis, sebaliknya Pasal 6 ayat (2) menyebut barang tidak sejenis, sehingga apabila demikian maka, Pasal 6 ayat (2) UUM 2001 yang memberikan perlindungan terhadap barang dan atau/ jasa tidak sejenis keberadaannya masih perlu diubah atau direvisi kembali.

Alasan yang dapat dikemukakan adalah karena doktrin pelanggaran merek adalah berbeda dengan doktrin dilusi merek dan substansi perlindungannya pun sama sekali berbeda dengan dilusi merek. Salah satu perubahan UUM 2001 yang relevan dengan Pasal 6 ayat (2) ini adalah dengan cara: Memisahkan ketentuan keduanya (pelanggaran merek dan dilusi merek) dalam urutan Pasal atau ayat yang berbeda misalnya dalam Pasal 6 ayat (2a) disertai penambahan penjelasan Pasal dengan sejelas-jelasnya dan tidak cukup dengan kata "Cukup Jelas" saja sebagaimana tertulis dalam penjelasan UUM 2001.

Namun demikian, apabila melalui cara di atas maka keuntungannya: a. tidak memerlukan pembuatan pengaturan tersendiri mengenai dilusi merek karena merupakan bagian yang digabungkan dalam satu kesatuan Undang-undang Merek; b. tidak memerlukan penguraian yang terlalu banyak dalam satu pasal dan hanya diuraikan dalam bagian penjelasan; c. Sumber hukum dari negara Indonesia yang menganut civil law sytem of law, yang mendasarkan pada perundang-undangan sehingga menjadi satu kepastian hukum tersendiri; sedangkan kerugiannya: a. Menempatkan pasal dilusi merek dengan pasal pelanggaran merek sekalipun hanya dalam urutan Pasal atau ayat yang berbeda dapat membuat penafsiran yang sama dari makna dilusi merek maupun pelanggaran merek; $b$.

14 Marcus H. H. Luepke, "Taking Unfair Advantage or Diluting a Famous Mark -- a 20/20 Perspective on the Blurred Differences Between u.s. and e.u. Dilution Law", The Law Journal of The International Trademark Association, Vol.98, No.3, May-June. 2008.

15 Natalie J. McNeal, “Trademark: Victoria's Dirty Little Secret: A Revealing Look At What The Federal Trademark Dilution Act Is Trying To Conceal", Oklahoma Law Review, Vol. 56, No.4, 2003, hlm. 977. 
Adanya doktrin baru membuat perundang-undangan menjadi gemuk karena berimplikasi juga pada akibat hukum dari adanya doktrin baru tersebut; c. Masalah penerimaan secara sosiologis mengenai pelaksanaan dan cara mengkomunikasikan kepada pemilik merek dan masyakarat sehingga betul bahwa doktrin dilusi merek ini dapat menjadi pilihan bagi perlindungan yang lebih luas bagi pemilik merek.

Berdasar pada keuntungan dan kerugian tersebut, maka pemisahan ketentuan baik dilusi merek dan pelanggaran merek bukan menjadi satu-satunya cara agar Pasal dilusi merek dapat diimplementasikan. Pilihan lain yang dapat dilakukan adalah dengan membuat Undang-undang secara tersendiri seperti halnya Federal Trade Dilution Act 1995 (FTDA) ataupun Trade Dilution Revision Act 2006 (TDRA) seperti yang berlaku di Negara Amerika Serikat. Undang-undang mengenai Dilusi Merek ini akan meliputi hal-hal seperti : pengertian dilusi, jenis dilusi, pembuktian dilusi, pelaksanaan dan interpretasi undang-undangnya.

Dalam kerangka perlindungan terhadap merek terkenal, Article 6 bis Konvensi Paris telah meletakkan dasar-dasar perlindungan yang baik, berisi ketentuan jaminan untuk level perlindungan yang lebih bagi merek terkenal, akan tetapi Pasal tersebut hanya melindungi merek terkenal dari adanya pelanggaran merek terkenal dan tidak melindungi merek tersebut dari dilusi merek terkenal. Dalam perkembangan berikutnya yaitu TRIPs, menggabungkan dan memperluas perlindungan untuk merek terkenal seperti yang ditata dalam Konvensi Paris. Pasal 16 ayat (3) yang berbunyi :

Article 6 bis of the Paris Convention (1967) shall apply, mutatis mutandis, to goods or services which are not similar to those in respect of which a trademark is registered, provided that use of that trademark in relation to those goods or services would indicate a connection between those goods or services and the owner of the registered trademark and provided that the interests of the owner of the registered trademark are likely to be damaged by such use. ${ }^{16}$

Pasal ini memulai dengan perpanjangan ruang lingkup perlindungan dari Article 6 bis Konvensi Paris untuk barang atau jasa tidak sejenis (non similar goods or services) asalkan beberapa kondisi dipenuhi. Pertama; merek terkenal harus terdaftar dan penggunaan merek yang lebih muda (younger mark) dalam kaitannya dengan barang atau jasa akan mengindikasikan adanya hubungan (connection) di antara barang atau jasa dengan pemilik terdaftar merek terkenal serta kepentingannya kemungkinan dirusak oleh penggunaan merek tersebut. ${ }^{17}$ Penggunaan merek terkenal oleh pihak lain adalah identik atau mirip dengan merek terkenal (karena itu dilarang oleh TRIPs) adalah sangat mirip terhadap gambaran klasik dari dilusi yang diungkapkan oleh Professor Schechter. ${ }^{18}$

Sebagaimana dapat dipahami dari kata-kata dalam pasal 16 ayat (3) serta pernyataan yang dikatakan Gervais, Pasal 16 ayat (3) melindungi melawan "dilution" atau dilusi merek, termasuk penggunaan merugikan dari reputasi merek. Pasal 16 ayat (3) TRIPs berlaku apabila terdapat penggunaan merek oleh pihak lain dengan barang atau jasa yang tidak sejenis terhadap merek terkenal yang sudah didaftarkan. ${ }^{19}$ Dalam praktek peradilan di Indonesia, terdapat penggunaan Pasal 16 ayat (3) TRIPs ini dapat dilihat dari beberapa putusan hakim sebagai berikut :

\footnotetext{
16 World Trade Organization, "TRIPs: Agreement On Trade-Related Aspects Of Intellectual Property Rights", https:/www.wto.org/english/ tratop e/trips e/t agm0 e.htm, diakses 29 Mei 2014.

Ibid.

18 Matthew C. Oesterle, "It's as Cleae as Mud : a Call to Amend The Federal Trademark Dilution Act of 1995", Chicago-Kent Law Review, Vol. 81, No.1, 2003, hlm. 252.

19 Özgün Altop dan Kubilay Özdemir, "The Protection of Well Known Marks and Marks with Reputation in Turkey and EU: Is Total Harmonization Possible and Desirable?”, http:/www.ip-masters.com/research/altop-ozdemir-2012.pdf, diakses 1 Desember 2015.
} 
Tabel 1.

Penggunaan Pasal 16 ayat (3) TRIPs Putusan

\begin{tabular}{|c|c|c|c|}
\hline No. & Nama Kasus & Putusan & Tahun \\
\hline & $\begin{array}{l}\text { Hawley \& Hazel (BVI) } \\
\text { Company Limited; Hawley } \\
\& \text { Hazel Chemical Co (HK) } \\
\text { LTD melawan Boediono } \\
\text { Djiptodihardjo. (Putusan } \\
\text { nomor 50/Pembatalan } \\
\text { Merek/2004/PN. Niaga Jkt Pst }\end{array}$ & $\begin{array}{l}\text { Menyatakan penggugat I dan Penggugat II sebagai para pemilik } \\
\text { yang sah yang berhak alas merek terkenal yang menggunakan kala } \\
\text { DARLIE + lukisan orang bertopi; } \\
\text {-Menyatakan hapus kekuatan hukum pendaftaran merek DARKIE } \\
\text { daftar nomor } 410650 \text { alas nama Tergugat I rekonpensi dan nomor } \\
365859 \text { atas nama Tergugat II rekonvensi dari daftar umum merek } \\
\text { dengan segala akibat hukumnva. }\end{array}$ & 2004 \\
\hline 2. & $\begin{array}{l}\text { Audemars Piguet Holding } \\
\text { SA melawan PT. Adi Perkasa } \\
\text { Buana (Perkara Nomor 06/ } \\
\text { Merek/2001) tanggal } 25 \\
\text { Februari 2002 }\end{array}$ & $\begin{array}{l}\text { Bahwa penggugat adalah pemilik merek terdaftar AUDEMARS } \\
\text { PIGUET dan merek AP untuk jenis barang-barang dalam kelas 14; } \\
\text { Bahwa merek AUDEMARS PIGUET termasuk merek terkenal } \\
\text { karena telah terdaftar di beberapa Negara dan telah menjadwalkan } \\
\text { promosi barang-barang di sekitar } 60 \text { kota di dunia; } \\
\text { Bahwa merek AUDEMARS PIGUET milik penggugat dan merek } \\
\text { AP AUDEMARS PIGUET milik tergugat telah digunakan untuk } \\
\text { barang yang tidak sejenis (not similar goods). }\end{array}$ & 2002 \\
\hline 3 & $\begin{array}{l}\text { Watson Enterprises Limited } \\
\text { melawan PT. Senshido } \\
\text { Beutyana Semesta dan Ditjen } \\
\text { HKI. (Putusan Nomor 14/ } \\
\text { Merek/2004/PN.Niaga.Jkt.Pst) }\end{array}$ & $\begin{array}{l}\text { Menyatakan bahwa PENGGUGAT adalah pemilik satu-satunya } \\
\text { yang berhak atas merek terkenal "WA TSON'S" di Wilayah } \\
\text { Republik Indonesia untuk membedakan hasil produksi Penggugat } \\
\text { dengan hasil produksi pihak lain; } \\
\text { Menyatakan merek Tergugat I "WATSON'S" dengan nomor } \\
\text { pendaftaran } 537.178 \text { mempunyai persamaan pada pokoknya dengan } \\
\text { merek terkenal "WATSON'S" milik Penggugat; } \\
\text { Menyatakan bahwa tindakan Tergugat I mengajukan pendaftaran } \\
\text { merek 'WATSON'S" dengan nomor pendaftaran } 537.178 \\
\text { mengandung itikad tidak baik karena meniru merek terkenal } \\
\text { "WATSON'S" milik Penggugat. }\end{array}$ & 2004 \\
\hline 4.. & $\begin{array}{l}\text { Gianni Versace S.p.A. } \\
\text { melawan Sutardjo Jono } \\
\text { (Putusan Nomor 77/ } \\
\text { Merek/2003/PN.Niaga.Jkt.Pst). }\end{array}$ & $\begin{array}{l}\text { Menyatakan Penggugat adalah pemilik satu-satunya yang } \\
\text { berhak atas Merek-Merek terkenal VERSUS, VERSUS GIANNI } \\
\text { VERSACE, VERSACE CLASSIC V2 dan VERSUS VERSACE } \\
\text { di wilayah Republik Indonesia untuk membedakan hasil produk } \\
\text { Penggugat dengan hasil produksi pihak lain; } \\
\text { Menyatakan bahwa tindakan Tergugat mengajukan pendaftaran } \\
\text { Merek V2 VERSI VERSUS dengan nomor pendaftaran } 361066 \\
\text { mengandung itikad tidak baik, karena meniru Merek-merek } \\
\text { terkenal milik Penggugat; } \\
\text { Menyatakan batal Merek Tergugat V2 VERSI VERSUS nomor } \\
\text { pendaftaran } 361066 \text { dalam Daftar Umum Merek Direktorat Jenderal } \\
\text { HAKI dengan segala akibat hukumnya. }\end{array}$ & 2003 \\
\hline
\end{tabular}


5. Diageo NorthAmericamelawan Pengadilan Niaga menyatakan bahwa: 1. Dasar pembatalan Stephen Rudy melawan Ditjen gugatan merek dagang untuk barang tidak sejenis (kelas berbeda) HKI milik penggugat dan tergugat adalah Pasal 16 Ayat (3) TRIPs, dikarenakan merek milik penggugat adalah merek terkenal dengan bukti sertifikat pendaftaran asing dan bukti-bukti ketenaran merek tersebut; 2. Pendaftaran merek dagang "Smirnoff" milik tergugat dilandasi dengan itikad tidak baik karena mempunyai persamaan pada pokoknya atas merek terkenal milik penggugat.

6. Inter IKEA System B.V Dalam putusan PN. Niaga : Bahwa IKEA adalah merek terkenal; melawan PT. Angsa Daya bahwa merek IKEMA mempunyai persamaan pada keseluruhan (Putusan Nomor 39/ atau setidak-tidaknya mempunyai persamaan pada pokoknya Merek/2011/PN.Niaga.Jkt.Pst) dengan merek terkenal IKEA;Bahwa merek IKEMA mempunyai jo Putusan MA No. 697 K/Pdt. itikad tidak baik; Menyatakan batal merek IKEMA.

Sus/2011) jo Putusan MA 165 Dalam putusan Kasasi MA: Bahwa judex facti tidak salah PK/Pdt.Sus/2012 menerapkan hukum, salah satu unsur persamaan pokok yaitu persamaan bunyi sebagaimana dalam Pasal 6 ayat 1 UUM 2001 telah terpenuhi, sehingga kasasi PT. Angsa Daya ditolak.

Dalam putusan PK MA: Bahwa penerapan Pasal 6 ayat (1) b yang dijadikan dasar untuk persamaan pada pokoknya tidak tepat; Bahwa penerapan Pasal 6 ayat 2 tidak dapat diterapkan pada kasus a quo karena Peraturan Pemerintah (PP) yang mengatur persyaratan tertentu tersebut belum diatur yaitu untuk menerapkan persamaan pada pokoknya untuk barang berbeda kelas. Sehingga ketentuan dalam konvensi belum dapat diimplementasikan.

Sumber: diolah Penulis, 2015.

Berdasarkan kasus di atas, majelis hakim masih dapat memberikan makna atas indikasi adanya suatu hubungan antara barang barang atau jasa dengan pemilik merek terkenal; bahwa atas merek yang digunakan oleh tergugat yang sama dengan merek pengugat, ada hubungan penggunaan merek yang sama sehingga disinilah letak indikasi tersebut, bukan dinilai berdasarkan disatu sisi merek milik penggugat maupun disisi yang lain merek milik tergugat, maka tidak mungkin ada indikasi. Dengan demikian, atas kerugian yang mungkin dialami oleh penggugat dengan merek tergugat bukan hanya di ukur dengan persentase atau ukuran angka-angka saja, akan tetapi juga kerugian secara reputasi dengan cara mengaburkan dan atau merusak keunikan atau ciri khas dari merek penggugat. Inilah yang disebut dengan dilusi merek.

Dilusi merek tidak mensyaratkan adanya kerugian secara materi juga adanya kesesatan maupun kebingungan masyarakat atas merek yang yang dilanggar oleh penggugat. Hal-hal seperti ini yang tidak diakomodir oleh rezim pelanggaran merek. Dengan dimuatnya unsur-unsur dilusi secara tersirat seperti tidak ada indikasi, tidak ada kerugian, tidak adanya kesesatan maupun kebingungan masyarakat yang disinggung oleh majelis dari pertimbangan putusan sebenarnya dapat menjadi awal yang baik dan dapat membuka peluang adanya pengaturan menuju perlindungan atas dilusi merek akan tetapi keberadaan Pasal 16 ayat (3) ini ternyata tidak dikaji lebih mendalam oleh majelis hakim.

Berdasarkan inventarisasi kasus yang diputus berdasarkan Pasal 16 ayat (3) TRIPs di atas sehingga memberikan konsekuensi dengan dikabulkannya gugatan penggugat dapat disimpulkan bahwa hakim dapat menggunakan aturan lain diluar dari UUM 2001 itu sendiri dengan alasan aturan yang digunakan adalah relevan dengan merek terkenal 
dengan perlindungan barang tidak sejenis. Pasal 16 ayat (3) TRIPs sendiri keberadaannya sudah diratifikasi di Negara Indonesia dengan UndangUndang Nomor 7 Tahun 1994 tentang Pengesahan Persetujuan Pembentukan Organisasi Perdagangan Dunia dan apabila merujuk pada sumber hukum yang dianut oleh negara Indonesia sudah mercerminkan dari ciri sumber hukum yang utama yaitu UndangUndang. Akan tetapi, dalam perkembangannya, adanya kelemahan yang ada dalam Pasal 6 ayat (2) UUM 2001, dapat menjadi masalah bagi pemilik merek terkenal itu sendiri.

Hal tersebut terbukti dalam kasus IKEA Inter IKEA System B.V. melawan IKEMA PT. Angsa Daya, dalam putusan PK ditemukan adanya novum untuk selanjutnya majelis hakim menetapkan bahwa penerapan Pasal 6 ayat (2) tidak dapat diterapkan pada kasus a quo karena Peraturan Pemerintah (PP) yang mengatur persyaratan tertentu tersebut belum diatur yaitu untuk menerapkan persamaan pada pokoknya untuk barang berbeda kelas sehingga ketentuan dalam konvensi belum dapat diimplementasikan. Dalam hal ini majelis hakim hanya melihat pada susunan huruf yang berbeda antara IKEA dan IKEMA sehingga disebutkan dalam putusan bahwa tidak terdapat persamaan pada pokoknya antara IKEA dengan IKEMA sebagaimana dinyatakan dalam Pasal 6 ayat (1) UUM 2001, kemudian ketika antara merek tersebut adalah berbeda kelas barang dan ternyata belum ada Peraturan Pemerintahnya dalam Pasal 6 ayat (2) UUM 2001 maka gugatan atas kasus tersebut menjadi tidak berdasar.

Alasan hakim yang menggunakan dasar belum adanya Peraturan Pemerintah dalam ketentuan Pasal 6 ayat (2) UUM 2001, dengan demikian secara tidak langsung, majelis hakim mengakui adanya perbedaan merek dengan jenis barang yang berbeda tersebut akan tetapi karena Peraturan Pemerintahnya belum ada maka tidak dapat diterapkan dalam kasus tersebut. Apabila dapat menggunakan metode penemuan hukum maka hakim dapat menemukan hukumnya secara tepat dan akurat terhadap peristiwa itu sehingga hakim dapat melengkapi dan menambah dasar-dasar gugatan yang diajukan oleh pihak-pihak yang berperkara sepanjang tidak merugikan mereka. Uraian putusan sebelumnya yang menggunakan dasar lain diluar UUM 2001 dapat dibandingkan yaitu dengan dasar Pasal 16 ayat (3) TRIPs, seharusnya hakim dapat melihat putusan hakim sebelumnya yang memberikan perlindungan dengan alasan Pasal 16 ayat (3) TRIPs untuk merek dengan jenis barang yang berbeda.

\section{Pengaturan Doktrin Dilusi Merek}

Dari beberapa kasus yang pernah diputus oleh hakim dengan menggunakan dasar Pasal 16 ayat (3) TRIPs, sebagaimana dibahas sebelumnya, maka sangatmungkin pengaturan dilusi merek di Indonesia dapat diterapkan dan dimasukan pengaturannya baik dalam UUM maupun pengaturan secara sendiri. Adapun mengenai memadai atau tidaknya mengenai karakteristik merek terkenal yang ada dalam Pasal 6 ayat (1) b, Penulis setuju Penjelasan Pasal 6 UUM 2001 sudah cukup memadai dalam memberikan penjelasan mengenai kriteria merek terkenal dengan mempertimbangkan hal yang sama pada kriteria merek terkenal pada Pasal 6 Konvensi Paris, TRIPs dan Joint Recommendation WIPO. Adapun mengenai ketentuan dalam penempatan jenis barang saja yang perlu diperjelas, ketika akan memutuskan kasus dilusi merek terkenal.

Mengenai efektif atau tidaknya dikembalikan kepada perundang-undangan yang berlaku dalam suatu negara tersebut tanpa menghilangkan kedinamisan dalam penentuan mengenai kriterianya. Oleh karena itu dalam pembahasan ini akan diuraikan mengenai: I. Prospek dalam perbaikan pengaturan Dilusi Merek di Indonesia dari sisi ekonomi, sosiologis dan budaya, kemudian; II. Pertimbangan dari segi perlindungan pemilik merek, persaingan usaha dan konsumen, kemudian; III. Rekomendasi Pengaturan Dilusi Merek di Indonesia, sebagai berikut: 
a. Prospek dalam Perbaikan Pengaturan Doktrin Dilusi Merek di Indonesia 1) Sisi Ekonomi

Perbuatan dilusi merek dapat mengurangi dan menurunkan reputasi merek sehingga merek terkenal kehilangan daya pembeda oleh karena nilai kekhasan dan keunikannya dikaburkan (blurring) atau dinodai (tarnishment) oleh pihak (merek) lain. Perbuatan dilusi dapat menimbulkan masalah ekonomi karena jenis barang atau jasa dengan kategori merek terkenal tidak dipergunakan secara efisien oleh karena ada pihak lain (pesaing) selain pemilik merek yang juga mengambil keuntungan dengan adanya keberadaan merek terkenal. Mekanisme pendistribusian barang oleh perusahaan tidak mencapai taraf maksimal untuk memperbaiki kesejahteraan masyarakat dimana masyarakat tidak mampu memperoleh barang yang dilekati merek yang terkenal dan asli.

Dilihat dari aspek kehilangan keuntungan penjualan sekalipun tidak perlu dibuktikan dalam pelanggaran atas dilusi merek, tetapi dengan adanya penggunaan merek yang sama walaupun barangnya tidak sejenis, tetap membuat aktivitas perdagangan tidak stabil, terutama pada penghitungan untung rugi. Adanya penghitungan tersebut meliputi hal-hal yaitu bahwa pemilik merek mempergunakan modal sendiri atau modal pinjaman yang dikenai bunga, ongkos bulanan, dan upah tenaga kerja yang semuanya harus diterima kembali dari hasil penjualan sehingga pemilik merek dapat membiayai pengeluaran hidupnya. Akan tetapi, kerugian ekonomis terbesar yang nyata adalah kehilangan reputasi dan kepercayaan konsumen atas merek terkenal yang dikaburkan dan dinodai. Padahal, upaya membangun reputasi itu memerlukan waktu yang tidak sebentar dan perjuangan yang sungguh-sungguh selama bertahuntahun sehingga menjadi goodwill atau reputasi dari masyarakat sebagai merek yang berkualitas dan diakui keterkenalannya.

\section{2) Sisi Sosiologis}

Sehubungan dengan adanya nilai-nilai sosiologis yang tidak terlepas dari unsur hukum, masyarakat pun terlibat, terutama terkait dengan fungsi merek itu sendiri sampai kemudian pada penggunaan barang yang dilekati merek terkenal. Dengan demikian, kesiapan pengaturan dilusi merek dari sisi sosiologis, dapat dipertimbangkan bahwa pertama, bagi masyarakat Indonesia, ada sebagian masyarakat yang menganggap bahwa membeli barang bajakan/palsu bukan merupakan masalah oleh karena keterbatasan ekonomi, sehingga bagi tipe masyarakat seperti ini, membeli barang tidak mengutamakan kualitas, tetapi hanya menimbang wujud saja; sebaliknya disisi sebagian masyarakat yang lain juga berfikir bahwa dengan membeli barang yang asli juga memberikan penghargaan terhadap pemilik mereknya dan tentu saja mengutamakan kualitas dan prestise ketika menggunakan barang yang dilekati merek terkenal tersebut.

Kedua, bagi pengusaha lokal yang dengan sengaja membonceng merek terkenal dengan membuat merek yang sama dengan merek terkenal, maka perlu diadakan perubahan paradigma yang secara terus-menerus melalui 
cara dan pendekatan sosiologi ataupun penyuluhan sehingga mereka tidak lagi melakukan pelanggaran. Ketiga, Adanya gugatan pelanggaran merek maupun pembatalan merek pengusaha asing yang mengajukan gugatan dikarenakan adanya pelanggaran merek oleh pengusaha lokal yang dengan gampangnya membuat merek yang sama dan tidak ingin membangun merek dari nol, melalui cara membonceng merek terkenal ketika terjadi pelanggaran merek dan ada pelanggarnya, masyarakat lebih memilih penyelesaiannya untuk dihukum (jalur litigasi) daripada jalur nonlitigasi. Padahal, hal itu dapat merugikan pengusaha dalam hal kelangsungan usaha dan kehilangan keuntungan. Sementara itu, masyarakat luar negeri lebih memilih uang kembali dalam bentuk ganti rugi daripada sebaliknya. (4). Iklim investasi dan perdagangan atas barang dan atau jasa merek terkenal memperlihatkan kemajuan yang signifikan. Hal ini dapat dibuktikan dengan keberadaan retail maupun showroom/gerai dengan label merek terkenal sehingga dapat memudahkan bagi masyarakat untuk mengakses kebutuhan dalam penggunaannya.

\section{3) Sisi Budaya}

Aspek hukum anti dilusi merek merupakan kaidah-kaidah hukum yang harus dibentuk pengaturannya dalam RUU Merek, ataupun dalam bentuk lain pengaturan yang terpisah. Adanya kaidah hukum ini tidak terlepas dari kondisi budaya bangsa Indonesia. Perkataan budaya atau culture ini di Indonesia lazimnya diterjemahkan dengan kebudayaan dengan titik berat kepada hasil hidup bersma di masyarakat, tidak ada kebudayaan yang diciptakan oleh seorang manusia saja atau hasil cipta seseorang saja. Mungkin penemuanpenemuan yang berarti diciptakan oleh pemikiran seseorang, tetapi penemuan itu akhirnya akan berkembang dan digunakan dalam masyarakat dalam kehidupan masyarakat itu, dan ide penemuan itu pun dihasilkan oleh manusia sebagai anggota masyarakat tertentu itu. ${ }^{20}$

Budaya masyarakat juga memberikan pengaruh dalam penegakan hukum merek meskipun masih ada sebagian dari masyarakat Indonesia yang beranggapan sulit untuk menerapkan ke dalam masyarakat yang masih menganut sifat komunal/ kolektivititas dari bentuk hak privat/ individu merek ini. Sesungguhnya bukanlah pertentangan antara sifat kolektivitas melawan sifat privat dari hak merek. Sifat hak privat merek yang berasal dari nilai hukum barat dan memberikan hanya pada perlindungan individual, seharusnya bukan dilihat dari sifat kolektivitas budaya bangsa Indonesia yang menganggap segala sesuatu adalah milik bersama.

Hal lain dalam pengembangan budaya bangsa Indonesia adalah adanya budaya jujur. Budaya jujur harus bermula dari tiap individu untuk tidak membajak atau membuat merek yang sama baik secara pokok maupun secara keseluruhan. Hal ini membawa implikasi bahwa bagi setiap merek yang dibuat berdasarkan ekspresi 
pembuatnya yaitu pemilik merek, merupakan merek yang dibuat sendiri secara jujur dan sesuai dengan produk yang dibuatnya. Sebaliknya adanya merek yang dibuat pun tidak mendilusi dengan cara mengaburkan apalagi menodai keberadaan dari merek terkenal. Oleh karena itu menjaga kejujuran merupakan tuntutan yang tidak dapat dielakkan demi menghormati dan melaksanakan penegakan hukum merek itu sendiri.

Sebagaimana diketahui bahwa bangsa Indonesia mempunyai akar nilai budaya tinggi yang memang digali dari budaya bangsa sejak dahulu. Budaya jujur juga adalah hal yang melekat sesuai dengan budaya ketimuran bangsa dan dijunjung tinggi sebagai nilai-nilai baik bangsa. Dengan demikian, berkenaan dengan pembahasan mengenai sisi budaya, maka budaya jujur dapat dipertimbangkan sebagai salah satu unsur pertimbangan dalam pengaturan dilusi merek di Indonesia.

b. Pertimbangan dari Sisi Perlindungan Pemilik Merek, Persaingan Usaha dan Konsumen

\section{1) Pertimbangan dari Sisi Perlin-} dungan Pemilik Merek

Pemilik merek terkenal mempunyai kesempatan untuk memperkuat mereknya menjadi "strong mark". Dengan demikian, ketika dihadapkan pada merek pihak lain yang sama atau mirip dalam kelas barang tidak sejenis serta dapat mengaburkan atau menodai bahkan merusak reputasi merek miliknya, pemilik merek dapat melindungi dirinya. Dalam kasus
Allied Maintenance Corp. v. Allied Mechanical Trades, Inc, oleh New York Court of Appeal, menyatakan bahwa :

Trademark owners have an interest in preventing the cancer-like growth arising from the use an identitical mark on dissimilar products or services which feeds upon the business reputation of an established distinctive trademark or name.

Pemilik merek mempunyai kepentingan dalam mencegah "pertumbuhan seperti kanker" yang timbul dari penggunaan merek yang identik pada "barang atau jasa yang tidak sejenis yang mempunyai reputasi yang berbeda dari merek dagang atau nama dagang". ${ }^{21}$ Adanya hal-hal lain, seperti faktor waktu, sertifikat kepemilikan merek, dan survei yang dilakukan oleh pengadilan dapat melengkapi gugatan dilusi. Dalam permohonan gugatan pemilik merek, kasus dilusi merek lebih banyak dimenangkan dibandingkan kasus pelanggaran merek biasa. Meskipun dilusi merek merupakan istilah yang relatif baru yang belum juga tertuang dalam peraturan perundang-undangan di Indonesia, dilusi merek dapat menjadi pilihan bagi pemilik merek untuk mempertahankan haknya dari para pelanggar merek.

Ketentuan perundang-undangan merek dapat melengkapi kekurangan yang ada dalam UUM 2001 dengan membuat penyelarasan dan harmonisasi atas Pasal 16 ayat (3) TRIPs mengenai perlindungan atas merek tidak sejenis terhadap UUM 
2001, selanjutnya memasukkan ketentuan dilusi merek sebagai bagian pengaturan yang tertuang dalam Pasal 6 ayat (2) UUM 2001, atau pun membuat perundang-undangan secara sendiri, penambahan pengaturan untuk merek tidak sejenis dalam Pasal 76 mengenai gugatan ganti rugi, perubahan dalam konsiderans dan penambahan Pasal tentang konsumen atau dalam jangka panjang dibuatkan pengaturan dalam perundang-undangan tersendiri. Dalam kerangka ini, Amerika Serikat membutuhkan waktu berpuluh-puluh tahun sejak ide Schechter, Model Law, Lanham Act, FTDA, kemudian TDRA untuk dapat memberi perlindungan dilusi merek terkenal menjadi gugatan yang tidak biasa dan banyak juga diputus di pengadilan.

Negara Indonesia dapat mengadopsi nilai-nilai baik atas ketentuan hukum yang ada pada common law system sejauh secara das sollen ataupun das sein dapat melindungi pemilik merek terkenal di Indonesia. Adanya pengembangan berbagai macam putusan di negara bagian Amerika Serikat sejak kemunculan kasus dilusi merek hingga kini dapat dijadikan bahan bagi pengadilan Indonesia untuk memasukan ketentuan hukum baru, yang akan lebih baik bila dimulai dari kerangka yuridis normatifnya terlebih dahulu.

\section{2) Pertimbangan dari Sisi Persaingan Usaha}

Pada masa dahulu, sebelum adanya pengaturan mengenai merek, adanya pelanggaran merek ini dikategorikan sebagai persaingan tidak jujur atau unfair competition. Persaingan tidak jujur dengan sendirinya bersifat melawan hukum karena undang-undang dan hukum memberikan perlindungan terhadap pergaulan yang tertib dalam dunia usaha. Dalam konteks Kekayaan Intelektual, pada prinsipnya pemilik hak diberikan hak eksklusif untuk menggunakan sendiri atau memberikan ijin kepada pihak lain dalam waktu tertentu sesuai dengan batasan yang ada dalam Undang-undang Kekayaan Intelektual. Akan tetapi, Kekayaan Intelektual diberikan pengecualian karena di dalamnya membutuhkan sumber daya dan waktu dalam upaya mendapatkannya.

Undang-Undang Kekayaan Intelektual sendiri menjamin bahwa penemuan paten dan lain-lain (termasuk merek) akan diberikan perlindungan sebelum dapat menjadi milik publik (public domain). Faktor ini menjadi penentu bagi perusahaan karena insentif ini dianggap sebagai jalan menguasai pasar tetapi tidak merupakan pelanggaran Undangundang. ${ }^{22}$ Sehubungan apabila ada niat pengusaha yang menghancurkan pasar kompetitor dengan cara mengaburkan atau mencemarkan/menodai reputasi merek terkenal maka untuk dapat dikatakan melanggar persaingan usaha tidak sehat harus memenuhi kegiatan yang dilarang meliputi : monopoli, meonopsoni, penguasaan pasar, persekongkolan, posisi dominan, jabatan rangkap, pemilikan saham, penggabungan, peleburan dan pengambilan saham, atau perjanjian yang dilarang meliputi: oligopoli, 
penetapan harga, pembagian wilayah, pemboikotan, kartel, oligopsoni, integrasi vertical, perjanjian tertutup, perjanjian dengan pihak luar negeri, trust menurut UU No.5/1999 tentang Larangan Praktek Monopoli dan Persaingan usaha tidak sehat.

Prospek pengaturan dilusi merek terhadap unsur persaingan usaha ini maka pengaturan akan memberikan hak merek yang dilindungi oleh negara dan undang-undang serta menjamin pemilik merek dengan hak untuk menggunakan ataupun memberikan izin kepada orang lain sesuai dengan batasan dalam undang-undang. Adanya pengaturan ini akan memberikan hak kepemilikan kepada pemilik hak merek untuk menggunakan secara baik dan benar tanpa melanggar hukum persaingan. Dengan perkataan lain, sebenarnya adanya hak yang diberikan kepada pemilik merek terkenal adalah monopoli legal yang dijamin undangundang.

Adanya hak eksklusif yang diberikan kepadanya merupakan kepemilikan mutlak yang mendekati monopoli yang diizinkan. Dengan demikian, pembatasan pun tetap dibutuhkan, misalnya melalui cara yang dilakukan KPPU dengan mengeluarkan Peraturan Komisi No. 02 Tahun 2009 tentang Pedoman Pengecualian Penerapan UU No. 5 Tahun 1999 berkaitan Hak Atas Kekayaan Intelektual.

\section{3) Pertimbangan dari Sisi Konsumen}

Keberadaan konsumen mempunyai peran penting sebagai pihak yang mengonsumsi barang atau jasa milik pemilik merek. Dengan begitu, pengaturan hukum antidilusi merek ini perlu diakomodasi di masa mendatang. Konsumen menjadi titik penting dalam menentukan adanya pelanggaran merek, tetapi tidak demikian dengan kasus dilusi merek. Asosiasi yang kemudian terbentuk dalam pikiran konsumen mengenai barang atau jasa yang mirip atau serupa dalam kelas barang tidak sejenis menjadi salah satu unsur yang dapat membuktikan suatu kasus merek terkenal untuk dapat dikategorikan melanggar dilusi merek. Oleh sebab tersebut, pengaturan hukum antidilusi merek di Indonesia menjadi penting dalam rangka menyelamatkan posisi konsumen sehingga menjadi konsumen yang cerdas dan taat kepada hukum. Dengan demikian, konsumen yang awam dapat terselamatkan dari kerugian-kerugian dan ekses negatif.

Dari segi hukum, perlindungan konsumen dapat menjamin tegaknya hak-hak konsumen terhadap para pelaku usaha yang tidak mempunyai itikad baik yang meraih keuntungan dengan memanfaatkan ketidaktahuan pengetahuan konsumen. Bagi konsumen, perlindungan segera akan barang atau jasa dengan merek terkenal di pasaran dengan UU Anti Dilusi menjadi hal yang tidak dapat terelakkan lagi mengingat segala gerak konsumen akan selalu berhadapan dengan pelaku usaha dan tentu saja produk yang dipasarkan di pasaran.

\section{c. Rekomendasi Pengaturan Dilusi Merek di Indonesia \\ Berdasarkan data, diketahui bahwa} ada beberapa variasi putusan hakim dalam memutuskan kasus merek dalam barang tidak sejenis, antara lain membatalkan merek, dianggap membonceng merek, melakukan itikad tidak baik, ataupun dianggap mengaburkan persepsi masyarakat akan 
asal-usul barang. Akan tetapi, tidak ada yang menggunakan dasar dilusi merek. Dalam kasus Hawley \& Hazel, Audemard Piguet Holding, Watson Enterprises Limited, Gianni Versace, Diageo North America, Inter IKEA System B.V., hakim sebenarnya telah secara responsif dan populis membuat pertimbangan hukumnya dengan menggunakan ketentuan Pasal 16 ayat (3) TRIPs yang memberikan perlindungan secara jelas bagi barang yang tidak sejenis berkategori merek terkenal dan terdaftar di beberapa negara.

Sejalan dengan kesiapan pengaturan dilusi merek pada masa mendatang, dilusi merek dapat diatur dengan syarat sudah diatur dalam perundang-undangan yang jelas dan tertuang dalam bunyi Pasal-pasalnya secara eksplisit yang disesuaikan dengan aturan dasar dalam konvensi internasional yang dalam hal ini Indonesia meratifikasinya dalam perundang-undangan nasional. Hal ini memberikan arti bahwa konsep dilusi merek dapat digunakan di Indonesia sehingga menjadi doktrin dilusi merek dengan jenis perlindungan seperti yang telah disebut dalam alinea sebelumnya, selanjutnya dikarenakan dilusi merek berkaitan dengan merek terkenal maka perlu dilakukan penentuan juga mengenai katagori merek terkenal, mengingat suatu merek belum tentu terkenal di negara lain.

Adanya kemiripan, seperti halnya dinyatakan dalam Undang-undang merek yang dibuat oleh negara tidaklah cukup menjadi pertimbangan sebagai merek terkenal. Dengan demikian, berdasarkan hal-hal tersebut maka penulis setuju hanya penentuan mengenai katagori merek terkenal saja yang dapat dipertimbangkan dan belum pada penentuan definisi secara ketat. Adapun dampak negatifnya, dikarenakan katagori bisa sangat berbeda-beda bagi tiap orang dan negara, memberikan konsekuensi pada ketidakpastian dalam pelaksanaannya dalam hal misalnya dibutuhkan adanya pendefinisian. Akan tetapi, disisi lain mengenai dampak positifnya yaitu bahwa Negara dapat menjamin bahwa apa yang telah ditentukan mengenai katagori merek terkenal maka hal itulah yang akan digunakan bilamana dibutuhkan dalam pelaksanaannya. Secara hukum, Negara Indonesia dapat pula mempersiapkan kerangka yuridis bagi perlindungan atas dilusi merek terkenal demi tegaknya kepemilikan dan perlindungan merek terkenal. Secara umum, TRIPs sudah memberikan grand design dalam Pasal 16 ayat (3), sedangkan sisanya dapat dikombinasikan dengan kepentingan Indonesia dan perundang-undangan yang terkait dengan merek. Bagi Indonesia, dilusi mungkin bukanlah konsep yang akrab (familiar) dan tertuang dalam peraturan perundang-undangan tentang Merek. Namun, penyelesaian menuju kearah terbentukya peraturan baru maka dalam amandemen RUU Merek mendatang, ketentuan Pasal 6 ayat (2) UUM dapat diperkuat dengan cara menambahkan Pasal atau ayat lain setelah Pasal 6 Ayat (2) UUM 2001 ataupun penguraian dalam penjelasannya secara jelas sehingga secara eksplisit menerjemahkan adanya perlindungan terhadap merek tidak sejenis yang merupakan representasi dari Pasal 16 ayat (3) TRIPs,

\section{Penutup}

Pemilik merek dapat menggugat pihak lain yang telah mendilusi mereknya dengan dengan menggunakan penyesuaian Pasal 6 ayat (2) UUM 2001 yang melindungi penggunaan merek barang dan atau jasa tidak sejenis yang terdaftar. Pasal ini merupakan adaptasi dari Pasal 16 ayat (3) TRIPs sebagaimana telah diratifikasi dalam Undang-Undang Nomor 7 tahun 1997 tentang pengesahan TRIPs. Adanya Pasal tersebut di atas dapat mengakomodir dilusi merek. Akan tetapi keberadaan Pasal ini masih harus dilengkapi dengan 
ketentuan Peraturan Pemerintah mengenai Merek Terkenal dan diadakan perubahan yang relevan dengan Pasal 6 ayat (2) UUM 2001. Adapun untuk mengisi adanya kekosongan Peraturan Pemerintah maka dapat dipergunakan Pasal 16 ayat (3) TRIPs tersebut sehingga tetap dapat memberikan perlindungan terhadap merek terkenal dalam barang atau jasa tidak sejenis.

Selain UUM 2001, ada beberapa perundangundangan yang dapat menjadi pelengkap ketika ketentuan hukum merek bersifat terbatas bahkan dapat dijadikan alternatif maupun bagian dalam pertimbangan putusan hakim, meliputi : 1. Pasal 1365 KUHPerdata mengenai Perbuatan Melawan Hukum (PMH). 2. Pasal 382 bis KUHP mengenai persaingan curang. Sejak Undang-undang merek No. 15/2001 disyahkan maka untuk penyelesaian kasus merek yang yang diadukan delik atau tindak pidananya sudah diatur secara sendiri dalam Bab XIV pada bagian ketentuan pidana. Dalam prospek perbaikan pengaturan dilusi merek di Indonesia perlu dipertimbangkan dari sisi ekonomi, sosiologis dan budaya.

Dari sisi ekonomi, maka dalam strategi 'perluasan merek yang dapat berpotensi menimbulkan dilusi merek'. Dari sisi sosiologis maka masyarakat pun terlibat, terutama terkait dengan fungsi merek itu sendiri sampai kemudian pada penggunaan barang yang dilekati merek terkenal. Masyarakat Indonesia harus diberikan pemahaman, pendampingan dan sosialisasi yang terus menerus guna mendukung serta memberikan penghargaan dan penghormatan terhadap pemilik merek terkenal yang telah bersusah payah membangun mereknya. Kemudian bagi pengusaha lokal, maka perlu diadakan perubahan paradigma yang secara terus-menerus melalui cara dan pendekatan sosiologi ataupun penyuluhan sehingga mereka tidak lagi melakukan pelanggaran.

Bagi setiap merek yang dibuat berdasarkan ekspresipembuatnyayaitupemilikmerek,merupakan merek yang dibuat sendiri secara jujur dan sesuai dengan produk yang dibuatnya. Sebaliknya adanya merek yang dibuat pun tidak mendilusi dengan cara mengaburkan apalagi menodai keberadaan dari merek terkenal. Berikutnya, pertimbangan dari sisi perlindungan pemilik merek, persaingan usaha dan konsumen. Kesiapan pelaku usaha dalam pengaturan yang sifatnya relatif baru, termasuk juga pengaturan secara perdata ataupun pidana terhadap unsur persaingan usaha karena pengaturan merek erat kaitannya dengan persaingan tidak jujur. Akibat terhadap konsumen, yaitu perlindungan dengan undang-undang antidilusi menjadi penting karena segala gerak konsumen akan selalu berhadapan dengan pelaku usaha dan tentu saja produk yang dipasarkan di pasaran.

Rekomendasi pengaturan dilusi merek di Indonesia yaitu dari sisi hukum, dilusi merek dapat diatur dan masuk dalam perbaikan/revisi RUU Merek mendatang dengan membuat pengaturan tersendiri atau memperkuat Pasal 6 ayat (2) UUM 2001 melalui cara menambahkan ayat lain kemudian menguraikan dalam bagian dalam Pasal 90 ayat (2) mengenai ketentuan pidana untuk barang dan/atau jasa tidak sejenis, hal ini dilatarbelakangi karena Pasal 90 hanya mengatur mengenai ketentuan pidana untuk barang dan/atau jasa sejenis. Selain itu dalam Pasal 76 kemungkinan ditambahkan lagi dalam ayatnya yaitu Pasal 76 ayat (2) mengenai gugatan untuk barang dan/atau jasa tidak sejenis.

\section{DAFTAR PUSTAKA}

\section{A. Buku}

Fahmi, Andi, et al., 2009, Hukum Persaingan Usaha Tidak Sehat Antara Teks dan Konteks, KPPU Republik Indonesia,Jakarta.

Nazir, Moh., 2003, Metode Penelitian, Ghalia Indonesia, Jakarta.
Shadily, Hassan, 1993, Sosiologi untuk masyarakat Indonesia, Penerbit Rineka Cipta, Jakarta.

\section{B. Artikel Jurnal}

Bhaskar, Brajendu, "Trademark Dilution Doctrine: The Scenario Post TDRA 2005", NJUS L. 
Rev, Oct-December, 2008.

Dogan, Stacey L. dan Lemley, Mark A., "The Trademark use Requirement in Dilution Cases", Santa Clara Computer \& High Technology Law Journal, Vol. 4, No. 3, 2008. Emerson, Patrick ,'I'm Litigatin' It: Infringement Dilution, and Parody Under the Lanham Act", Northwestern Journal of Technology and Intellectual Property, Vol. 9, No. 7, 2011.

Luepke, Marcus H. H., “Taking Unfair Advantage or Diluting a Famous Mark -- a 20/20 Perspective on the Blurred Differences Between u.s. and e.u. Dilution Law", The Law Journal of The International Trademark Association, Vol. 98, No. 3, May-June. 2008.

McNeal, Natalie J. “Trademark: Victoria's Dirty Little Secret: A Revealing Look At What The Federal Trademark Dilution Act Is Trying To Conceal", Oklahoma Law Review, Vol. 56, No. 4, 2003.

Oesterle, Matthew C., "It's as Cleae as Mud : a Call to Amend The Federal Trademark Dilution Act of 1995", Chicago-Kent Law Review, Vol. 81, No. 1,2003.

Vuk, William T., "Protecting Baywatch And Wagamama: Why The European Union Should Revise The 1989 Trademark Directive To Mandate Dilution Protection For Trademarks", Fordham International Law Journal, Vol. 21,No. 3, 1997.

\section{Internet}

Alexander, Miles J. , et al., "The Historic FoundSation of the Dilution Doctrine in Trademark Law", www. ipworld.com, diakses 1 Desember 2015.

Altop, Özgün dan Özdemir, Kubilay, "The Protection of Well Known Marks and Marks with Reputation in Turkey and EU: Is Total Harmonization Possible and Desirable?", http://www.ip-masters.com/research/altopozdemir-2012.pdf, diakses 1 Desember 2015.
Citrawinda, Cita, "Sekilas Tentang Tindak Pidana dalam Bidang Merek", http://iwan09file. wordpress.com/mengenai-permasalahanmerek/, diakses 21 Desember 2013.

Cornel University Law School, " Dilution: Trademark" , https://www.law.cornell.edu/ wex/dilution_trademark, diakses 1 Desember 2015.

Dogan, Stacey L., "What is dilution, anyway?", http://students.law.umich.edu/mlr/ firstimpressions/vol105/dogan.pdf, diakses 1 Desember 2015.

Harvard Universiry, "Overview of Trademark Law" http://cyber.law.harvard.edu/metaschool/ fisher/domain/tm.htm, diakses 1 Desember 2015.

World Trade Organization, "TRIPs: Agreement On Trade-Related Aspects Of Intellectual Property Rights", https://www.wto.org/ english/tratop_e/trips_elt_agm0_e.htm, diakses 29 Mei 2014.

\section{Peraturan Perundang-undangan}

Undang-Undang Nomor 15 Tahun 2001 tentang Merek (Lembaran Negara Republik Indonesia Tahun 2001 Nomor 110, Tambahan Lembaran Negara Republik Indonesia Nomor 4131).

\section{E. Putusan}

Putusan Nomor 50/Pembatalan Merek/2004/PN. Niaga Jkt Pst. Hawley \& Hazel (BVI) tentang Kasus Company Limited; Hawley \& Hazel Chemical Co (HK) LTD melawan Boediono Djiptodihardjo.

Perkara Nomor 06/Merek/2001) tanggal 25 Februari 2002 tentang Kasus Audemars Piguet Holding SA melawan PT. Adi Perkasa Buana.

Putusan Nomor 14/Merek/2004/PN.Niaga.Jkt.Pst) tentang Kasus Watson Enterprises Limited melawan PT. Senshido Beutyana Semesta dan Ditjen HKI. 
Putusan Nomor 77/Merek/2003/PN.Niaga.Jkt.

Pst) tentang Kasus Gianni Versace S.p.A. melawan Sutardjo Jono.

Putusan Nomor 39/Merek/2011/PN.Niaga.Jkt.Pst) jo Putusan MA No. 697 K/Pdt.Sus/2011) jo. Putusan MA 165 PK/Pdt.Sus/2012 tentang Kasus Inter IKEA System B.V melawan PT. Angsa Daya. 